\title{
MARGINALISASI GAMELAN BATEL DALAM SENI PERTUNJUKAN WAYANG KULIT DI DESA SIBANGGEDE, KABUPATEN BADUNG
}

\author{
Oleh: \\ I Nyoman Surianta \\ Program Pasca Sarjana Universitas Udayana Denpasar \\ e-mail:wulancoe@yahoo.co.id
}

\begin{abstract}
The marginalization of the Gamelan Batel in Sibanggede Village can be observed in the form of the decrease of the traditional art values in the society, the displacement of traditional arts, the secularization of the traditional art, the narrowing of the traditional art performances, the hegemony of the modern art to that of the traditional one. Second, there are two factors that cause the Gamelan Batel in Sibanggede Village to be marginalized, namely, internal and external factors. The internal factors include lack of talent, lack of public interest, lack of open attitude, lack of funding from the government. The external factors are economics, technology and information, the function shift of the traditional gamelan. Third, the impact of the marginalization of the Gamelan Batel in Sibanggede Village is in the form of the failure to form regeneration, failure of reconstruction effort, failure of revitalization effort.
\end{abstract}

Keywords: marginalization, art, gamelan batel

\begin{abstract}
Abstrak
Bentuk marginalisasi Gamelan Batel di Desa Sibanggede dapat dilihat dengan menurunnya nilainilai seni tradisi di masyarakat, tergesernya kesenian tradisi, sekuralisasi seni tradisi, penyempitan ruang pentas seni tradisi, hegemoni seni tradisi oleh seni modern. Kedua, fakto-faktor yang menyebabkan Gamelan Batel di Desa Sibanggede termarginalisasi disebabkan oleh dua faktor yaitu faktor internal dan eksternal. Faktor dari dalam antara lain, kurangnya bakat, kurangnya minat masyarakat, kurangnya sikap yang terbuka, kurangnya bantuan dana dari pemerintah. Faktor eksternal antara lain, ekonomi, teknologi dan informasi, alih fungsi dalam gamelan tradisi. Ketiga, dampak marginalisasi Gamelan Batel di Desa Sibanggede, berupa gagalnya membentuk regenerasi, gagalnya usaha rekontruksi, gagalnya usaha revitalisasi.
\end{abstract}

Kata kunci: Marginalisasi, seni, gamelan batel

\section{PENDAHULUAN}

Gamelan Bali merupakan warisan budaya oleh para pendahulu dan sampai sekarang masih ditekuni dan dipertahankan. Eksistensi kehidupan gamelan Bali tidak dapat dipisahkan dari agama khususnya agama Hindu, walaupun dalam perkembangannya gamelan Bali mempunyai dominasi dalam berbagai jenis pertunjukan yang tidak ada dalam konteks agama, namun dia tetap eksis sampai saat ini (Bandem,1982: 2). Di Bali terdapat kurang lebih 30 jenis barungan 
gamelan yang masing-masing mempunyai instrument, reportoar, tehnik permainan, bentuk, fungsi, makna, dan pendukung seniman yang berbeda-beda (Sukerta, 2009: 1). Salah satu jenis barungan dari 30 jenis barungan di Bali ini, akan menjadi objek penelitian dari tulisan ini yaitu Gamelan Batel di desa Sibanggede, Kecamatan Abiansemal, Kabupaten Badung.

Keberadaan Gamelan Batel tersebut diceritakan mulai dipelajari seniman di desa Sibanggede atas kebutuhan yang dirasa sangat penting di dalam kehidupan masyarakat. Selain itu Gamelan Batel di Sibanggede mempunyai fungsi yang sangat erat hubungannya dengan upacara keagamaan Hindu. Dalam upacara dewa yadnya misalnya, di masing-masing rumah atau di pura-pura pemaksan (paibon), dalam prosesi upacara keagamaan Hindu masyarakat Sibanggede selalu melibatkan gamelan batel ini. Dalam upacara keagamaan di Sibanggede lebih sering menggunakan gamelan batel, dikarenakan pada saat itu jarang ditemui gamelan lain, seperti halnya gong kebyar.

Kondisi itu berlangsung cukup lama dimana untuk cerita Ramayana iringan gamelannya adalah gamelan batel sedangkan untuk iringan cerita Brata Yuda diiringi oleh gamelan gender. Hal ini berlangsung sampai di tahun dua ribuan, setelah munculnya kreativitas baru kemudian gamelan batel mulai digantikan oleh kehadiran gamelan lain yang digunakan untuk mengiringi wayang kulit seperti halnya gamelan samara pagulingan, angklung, gong kebyar.

Dengan kata lain, kesenian dewasa ini, secara kuantitas mengalami perkembangan yang sangat luar biasa. Tetapi perkembangan yang begitu dasyat ini tidak diikuti oleh beberapa kesenian yang lain. Di satu sisi ada yang mengalami perkembangan yang dasyat di sisi lain ada kesenian yang sedang mengalami keterpinggiran, yang diakibatkan oleh minimnya perhatian terhadap kesenian tersebut. Dari pemaparan latar belakang di atas maka dalam penelitian ini dapat diidentifikasikan rumusan masalah sebagai berikut:

(1) Bagaimana bentuk marginalisasi Gamelan Batel dalam seni pertunjukan Wayang Kulit di Desa Sibanggede?

(2) Faktor-faktor apakah yang menyebabkan Gamelan Batel di Desa Sibanggede termaginalisasi?

(3) Bagaimana dampak dan makna marginal- isasi Gamelan Batel dalam seni pertunjukan Wayang Kulit di Desa Sibanggede?

\section{PEMBAHASAN}

Penelitian berparadigma budaya yang dalam realitas pendekatannya menekankan konsep bentuk. Ratna (2010: 344) menyatakan analisis kajian budaya, sebagai analisis ilmiah jelas harus mempertimbangkan keseimbangan antara bentuk dan isi, sebagai kesimbangan yang proporsional, baik dalam kaita dengan komposisi maupun argumentasi. Dalam kaitan ini, keterwujudan atau bentuk menandai keberadaan sesuatu yang fenomenal dapat dicapai dan digapai secara indrawi sehingga dapat diperoleh fakta-fakta empirik. Fakta-akta empirik seperti peristiwa dan gejala kealaman yang terlihat oleh manusia, masyarakat dan kebudayaan itu dihubungkan dan diangkat saripatinya. Dengan demikian, maka pengetahuan kebenaran obyektif tentang sesuatu apa yang berbentuk itu menjadi menyeluruh dan tuntas.

Seni pertunjukan tradisi kini semakin terpinggirkan akibat perkembangan jenis kesenian lain yang dianggap mempunyai daya guna komplek dan signifikan di masyarakat. Gamelan Batel di desa Sibanggede sebagai contoh, kemungkinan hanya bisa disaksikan di acara-acara minimalis, yang upacaranya bisa dikatakan sebagai pemuput wali saja. Bahkan keberadaan dari Gamelan Batel sekarang ini mengalami keterpurukkan yang sangat memprihatinkan, sebagian masyarakat pendukungnya mulai tidak menghiraukan nilai-nilai luhur yang terkandung dalam gamelan Batel gender wayang ini.

Di Bali gamelan tidak asing lagi dalam kehidupan orang Bali. Orang Bali menjalani roda kehidupan hampir selalu memerlukan gamelan, kehidupan orang Bali, kehidupan yang berdasarkan yadnya. Masyarakat Bali selalu menyatu dengan kehidupan yang tidak biasa lepas dari yadnya. Kesenian dalam yadnya adalah sebagai penyemarak dalam upacara yadnya di Bali. Hampir setiap yadnya di Bali selalu mengikutsertakan kesenian dalam pelaksaannya. Menurut Suartaya (1993: 128), gamelan Bali adalah alat pengikat solidaritas suatu kolompok atau komunitas. Bahkan gamelan itu sendiri merupakan cermin dari suatu kedudukan dan struktur masyarakat. 
Gamelan Batel gender wayang dewasa ini, telah mengalami pergeseran peran. Kelangsungan hidup kesenian Batel ini mulai di ambil alih oleh gamelan lain. Gamelan Batel yang dulunya menjadi salah satu barungan pengiring pertunjukan wayang kulit, pada kenyataannya sekarang sudah ditinggalkan, dan tidak diikut sertakan dalam pertunjukan wayang kulit. Seni yang pernah ada di tengah-tengah masyarakat ini tidak hanya telah terpinggirkan, bahkan acapkali berbenturan dengan pemahaman serta pandangan keagamaan. Padahal sangat jelas kalau seni tradisi adalah segala hal yang tumbuh dan berkembang di masyarakat akibat dukungan dari masyarakatnya sendiri. Sudah selayaknya masyarakat dimana kesenian itu tumbuh harus dilestarikan dan dikembangkan oleh masyarakat sendiri kalau tidak ingin kesenian yang mereka warisi hilang tertelan zaman.

Dilihat dari sisi kemajuan seni di daerah Bali pada umunya, sudah barang tentu sangat memuaskan, ini bisa kita lihat dari banyaknya muncul kesenian-kesenian yang baru, begitu juga dengan kreatifitas senimannya untuk memajukan kesenian kesenian yang mereka warisi. Kenyataannya dalam berkembangnya kesenian dewasa ini, justru dibalik perkembangan yang sangat memuaskan ini, ternyata ada kesenian yang justru mengalami keterpinggiran dari harike hari. Kesenian gamelan batel gender wayang ini adalah salah satu jenis kesenian yang termasuk kesenian yang mengalami keterpinggiran yang sangat memprihatinkan. Masyarakat Sibanggede adalah masyarakat yang mayoritas penduduknya bekerja sebagai petani.Kehidupan kesehariannya disibukkan dengan pekerjaan yang ada di sawah. Di samping sebagai petani masyarakat Sibanggede juga berpenghasilan sebagai wiraswasta, PNS, dan lain sebagainya. Melihat kondisi seperti ini, sudah barang tentu kesenian hanya dijadikan sebagai sebuah hiburan belaka hanya dipakai untuk mengisi waktu luang.

Persoalan bakat dan pengaruh lingkungan sekitar dapat dilihat sebagai bagian dari debat mengenai "bawaan vs asuhan". Howe, Davidson, dan Sloboda berpendapat bahwa perbedaan individu dalam bermain musik dan kemampuan lain hanya disebabkan oleh latihan, sehingga mereka tetap mempertahankan bahwa " asuhan" adalah faktor yang dominan. Walaupun setiap orang mengakui bahwa genetika dan inter- aksi lingkungan telah mulai sejak in oteru (dalam kandungan), tetapi masih sulit menjelaskan interaksi bawaan yang komplek dalam prestasi musik (Djohan, 2009: 218).

Dari banyaknya jumlah penduduk di Desa Sibanggede, yang terdiri dari 12 banjar, dapat menunjukan bahwa banyaknya kelompok muda-mudi yang ada di masing-masing banjar. Tetapi dalam usaha untuk meningkatkan kesenian, khususnya kesenian batel gender wayang bisa dikatakan tidak ada yang peduli dengan kesenian ini lagi. Para muda mudi yang ada di daerah Sibanggede lebih tertarik untuk mempelajari gamelan yang lain seperti halnya gong kebya. Dalam pengembangan pelestarian sebuah kesenian seperti halnya gamelan batel ini, perlu adanya dua kekuatan yang mempunyai peranan penting, yang pertama seniman mempunyai peranan mencipta, mengapresiasi, dan mensosialisasikan, sedangkan masyarakat mempunyai peranan untuk mengapresiasi, mendukung, dan melestarikan sebagai hasil dari sebuah kebudayaan. Jika kedua kekuatan yang penting ini bersatu padu mendukung maka niscaya Gamelan Batel akan mendapat tempat yang baik di masyarakat sesuai dengan fungsinya.

Kehadiran Gamelan Batel wayang kulit pada dasarnya berkembang karena pelaku-pelaku yang terlibat di dalam proses pertunjukan wayang kulit menunjukan suatu jaringan. Gamelan Batel itu sendiri hadir karena kreatif yang dilakukan oleh para seniman untuk menciptakan suatu produk seni yang lazimnya lumrah adanya saat itu. Kepopuleran itu bisa jadi mendapat dorongan dari gamelan gender, batel dan penabuh yang mampu membawakan instrumen tersebut dengan baik. Hal lain yang menjadi faktor yang datang dari luar sebagai penyebab kendornya peran gamelan batel adalah kebutuhan masyarakat terhadap seni tradisi termasuk gamelan batel yang mengiringi wayang kulit tidak lagi menjadi pilihan masyarakat sebagai bagian dari bentuk hiburan.

Ada kecendrungan pada masyarakat saat ini telah kehilangan budaya karena persoalan waktu yang dimiliki sudah habis untuk menyiapkan kegiatan yang berkaitan dengan pekerjaan rutinitas. Kenyataan itu malah berdampak pada perhatian yang semakin berkurang pada budaya-budaya lokal yang berbau tradisi. Dulu masih banyak masyarakat yang memanfaatkan kegiatan pertunjukan wayang kulit dengan iringan 
Gamelan Batel dalam upaya untuk menghibur masyarakat. Dalam budaya pertunjukan yang berkembang di Bali tampaknya eksplorasi gamelan dalam mengiringi sebuah pertunjukan merupakan hal yang unik ketika terjadi perubahan pengiring dari gamelan pengiring yang biasa mengiringi sebelumnya ke bentuk pengiring gamelan yang dianggap berbeda, walau barungan gamelan yang dimaksud masih berstatus lama, seperti yang dilakukan dalam pertunjukan wayang kulit dekade ini sering sekali ditemukan bahwa iringan gamelan yang digunakan untuk mengiringi pertunjukan wayang kulit mengalami perubahan ansambel atau barungan alat gamelan.

Mulai dari gamelan semar pagulingan, angklung, gong gede, semarandana sebagai pengganti Gamelan Batel. Bergesernya bentuk iringan itu tidak lain dari kehendak para intelektual seniman karawitan dalam menunjukan karyanya yang dianggap berbeda sebagai suatu upaya untuk mencoba mencari suatu alternative baru. Penyebabnya adalah kebutuhan yang mengharuskan setiap seniman yang berurusan dengan akademik senantiasa dituntut karya-karya yang baru sebagai bentuk pengembangan karya tradisi. Hal yang tidak dapat dihindari dari perubahan itu adalah kehendak sang dalang yang juga merasa penting untuk melakukan perubahan dari berbagai sisi sehingga wayang yang dulu sangat ketat dengan pola pakem yang kuat menjadi terbiasa dengan sentuhan-sentuhan yang lebih dinamis dan menarik di luar pakem yang ada. Hal itu memang sangat dianjurkan sang dalang, hanya saja memang ada beberapa pakem yang tampaknya tidak boleh secara sembarangan dilakukan perubahan dalam pertunjukan wayang kulit.

Kajian dampak dan makna marginalisasi Gamelan Batel di Desa Sibanggede menyikapi beberapa permasalahan yang muncul dan terjadi sebagai dampak dari bentuk marginalisasinya Gamelan Batel di desa Sibanggede. Gencarnya arus berkesenian yang ada dewasa ini justru dilakukan oleh senimannya sendiri, tampaknya memberi kontribusi yang signifikan terhadap keterdesakan terhadap sejumlah kesenian tradisioanal Bali. Sudah terhitung banyak kesenian tradisional terancam mengalami kepunahan lantaran sekarang ini sudah sangat jarang sekali untuk mendapatkan kesempatan untuk melakukan pementasan. Bahkan ada yang dian- taranya sudah mengalami kepunahan dan lenyap tanpa bekas. Kekawatiran terjadinya sejumlah kematian masal jenis-jenis kesenian tradisional pun menyeruak. Jika upaya untuk merekonstruksi kesenian-kesenian tradisional tersebut tidak dilakukan secepatnya niscaya kesenian-kesenian ini akan akan lenyap keberadaannya.

Merekonstruksi berarti menggali atau menghidupkan kembali segala sesuatu yang dulunya pernah ada. Dalam hal ini dimaksudkan untuk menghidupkan kembali dan membangkitkan Gamelan Batel yang ada di desa Sibanggede, dari keterpinggiran dan keterdesakan oleh kesenian lain yang telah mengambil alih posisi Gamelan Batel untuk mengiring pertunjukan wayang kulit. Merekonstruksi juga berarti menata ulang, baik dari instrumennya, reportoarnya, ataupun bentuk penyajiannya. Selama ini yang terjadi bahwa Gamelan Batel di desa Sibanggede, kurang mendapat perhatian dari hal penataan instrument, serta gending-gending yang dimainkan, baik dari kalangan seniman pendukungnya maupun oleh pihak pemerintah. Dari pengamatan penulis selama melakukan penelitian baik terhadap alat (instrumentasinya) ataupun reportoar lagunya, dapat dijumpai sudah banyak alat-alat atau instrmentasinya dalam keadaan tidak bisa digunakan lagi, seperti misalnya kendang keadaannya sudah rusak, namun beberapa masih bisa dipergunakan. Demikian juga repoartoar lagunya ada beberapa bagian yang sudah dilupakan oleh sekaa.

\section{SIMPULAN DAN SARAN}

Adapun bentuk kesenian Gamelan Batel di desa Sibanggede secara pertunjukan merupakan bentuk iringan wayang kulit yang terdiri dari beberapa alat atau instrumen musik yang digabung dalam satu ensambel yang disebut Gamelan Batel. Secara struktur bentuk gending terdiri dari gendingpetegak atau pemungkah yang berfungsi sebagai penanda dimulainya wayang kulit. Selanjutnya beberapa bentuk struktur gending tergabung dalam susunan aransemen gending yang disebut gending pengiring yang fungsinya berkaitan penuh dengan karakteristik cerita wayang yang dimainkan. Beberapa namagending yang dimainkan adalah seperti pemungkahgedog, gamelan kayonan, gamelan tualen, rebong, mesem, angkat-angka- 
tan, bebatelan, sampai dengan penutup. Keberadaan Gamelan Batel di desa Sibanggede dapat dikatakan bahwa secara umum ada dua faktor penyebab yang diurai atas dasar faktor internal dan faktor eksternal. Faktor internal yang dimaksud adalah penyebab yang datang dari dalam yakni temuannya adalah kurangnya bakat, kurangnya minat dari masyarakat, kurangnya sikap terbuka dalam menerima pembaharuan sehingga struktur gending yang dimainkan seolah tidak mengalami kebaharuan. Padahal kebaharuan gending di dalam pengiring wayang kulit saat ini dianggap sebagai karya yang potensial sebagai magnet pertunjukan.

Kesenian Gamelan Batel di Sibanggede adalah salah satu warisan budaya tradisional Bali, yang hingga kini keberadaannya kurang eksis di tengah-tengah masyarakat pendukungnya. Di kalangan masyarakat Gamelan Batel merupakan warisan budaya yang bernilai tinggi, atau kesenian yang memiliki kekuatan magis, oleh karena itu demi kelestarian Gamelan Batel hendaknyalah masyarakat Sibanggede mempertahankan
Gamelan Batel. Dengan mensosialisasikan kepada pelaku penerus seni di desa Sibanggede untuk mempelajari dan mempertahankannya.

\section{UCAPAN TERIMA KASIH}

Ucapan terima kasih yang sedalam dalamnya penulis sampaikan kepada Prof. Dr. I Nyoman Suarka, M. Hum, selaku pembimbing satu, Dr. I Gede Arya Sugiarta, S.Skar.,M. Hum, selaku pembimbing dua, yang dengan penuh perhatian telah memberikan bimbingan, tuntunan, dan saran selama penulis menyelesaikan tesis ini. Rasa hormat dan terimakasih juga ditujukan kepada bapak Rektor, Prof. Dr. dr. Ketut Suastika SpPD KEMD, atas kesempatan yang diberikan kepada penulis dalam mengikuti program pendidikan magister di Universitas Udayana. Ucapan yang sama juga penulis sampaikan kepada ibu Prof. Dr. dr. A.A. Raka Sudewi, SpS (K) Direktur program Pascasarjana UNUD.

\section{DAFTAR PUSTAKA}

Bandem, 1982. Karawitan Bali. Denpasar: Akademi Seni Tari Indonesia Denpasar

Djohan. 2009. Psikologi Musik. Jogjakarta: Best Publisher

Ratna, I Nyoman Kutha. 2010. Metodologi Penelitian Kajian Budaya dan Ilmu-ilmu Sosial Humaniora Pada Umumnya. Yogyakarta:Pustaka Pelajar

Sukerta, Pande Made. 2009. Gong Kebyar Buleleng: Perubahan dan Keberlanjutan Tradisi Gong Kebyar. Surakarta: Program Pascasarjana bekerjasama dengan ISI Press Surakarta.

Suartaya, Kadek. 1993." Drumband Tradisional Adi Merdangga Kreatifitas Seni Berdimensi Universal". Dalam Mudra Jurnal Seni Budaya, Sekolah Tinggi Seni Indonesia Denpasar: STSI Press. 